Supporting Information

for

\title{
N-hydroxyphthalimide: a Hydrogen Atom Transfer (HAT) Mediator in Hydrocarbon Oxidations Promoted by Nonheme Iron(IV)-oxo Complexes
}

Alessia Barbieri, Osvaldo Lanzalunga,* Andrea Lapi, Stefano Di Stefano

Spectrophotometric analysis of the reaction of $\left[(\mathrm{N} 4 \mathrm{Py}) \mathrm{Fe}^{\mathrm{IV}}=\mathrm{O}\right]^{2+}$ with $20 \mathrm{~mol} \%$ of X-NHPI mediators

Kinetic study of the reaction of $\left[(\mathrm{N} 4 \mathrm{Py}) \mathrm{Fe}^{\mathrm{IV}}=\mathrm{O}\right]^{2+}$ with $4-\mathrm{NO}_{2}-\mathrm{NHPI}$

Kinetic studies of the oxidation of triphenylmethane with $\left[(\mathrm{N} 4 \mathrm{Py}) \mathrm{Fe}^{\mathrm{IV}}=\mathrm{O}\right]^{2+}$ in the Presence of $N$-hydroxyphthalimide mediator

Kinetic studies of the oxidation of triphenylmethane with $\left[(\mathrm{N} 4 \mathrm{Py}) \mathrm{Fe}^{\mathrm{IV}}=\mathrm{O}\right]^{2+}$ in the presence of $20 \mathrm{~mol} \%$ of X-NHPI mediators

Kinetic studies of the oxidation of alkylaromatic compounds and cyclohexane with $\left[(\mathrm{N} 4 \mathrm{Py}) \mathrm{Fe}^{\mathrm{IV}}=\mathrm{O}\right]^{2+}$ in presence of $20 \mathrm{~mol} \%$ of NHPI mediator 
Spectrophotometric analysis of the reaction of $\left[(\mathrm{N} 4 \mathrm{Py}) \mathrm{Fe}^{\mathrm{IV}}=\mathrm{O}\right]^{2+}$ with $\mathrm{X}-\mathrm{NHPI}$ mediators

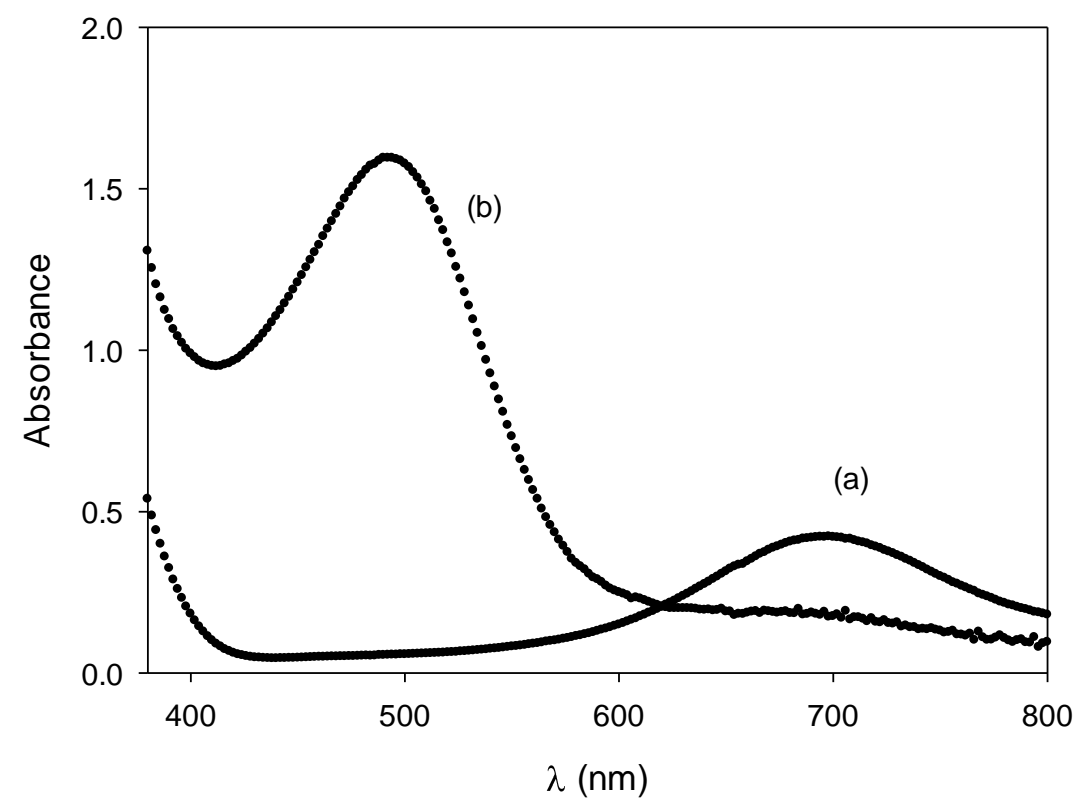

Figure S1. Absorption spectra of the $\left[(\mathrm{N} 4 \mathrm{Py}) \mathrm{Fe}^{\mathrm{IV}}=\mathrm{O}\right]^{2+}\left(1.5 \mathrm{mM}\right.$ in $\left.\mathrm{CH}_{3} \mathrm{CN}\right)(\mathrm{a})$ in the absence and (b) after addition of 1 equivalent of 4- $\mathrm{CH}_{3} \mathrm{O}-\mathrm{NHPI}$.

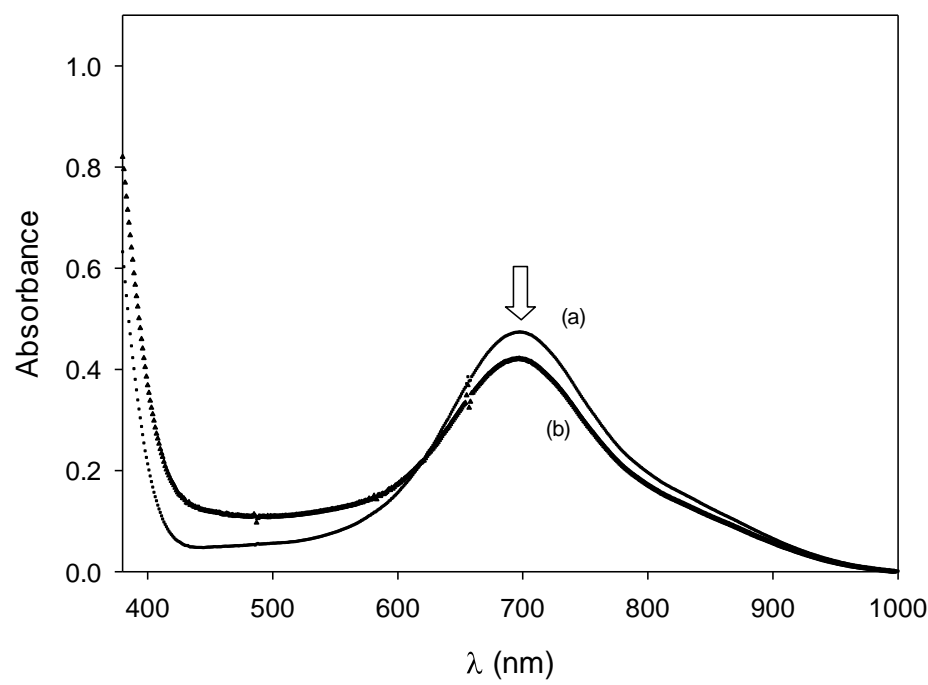

Figure S2. Absorption spectra of the $\left[(\mathrm{N} 4 \mathrm{Py}) \mathrm{Fe}^{\mathrm{IV}}=\mathrm{O}\right]^{2+}\left(1.5 \mathrm{mM}\right.$ in $\left.\mathrm{CH}_{3} \mathrm{CN}\right)$ (a) in the absence and (b) after addition of $20 \mathrm{~mol} \%$ of 3-F-NHPI. 


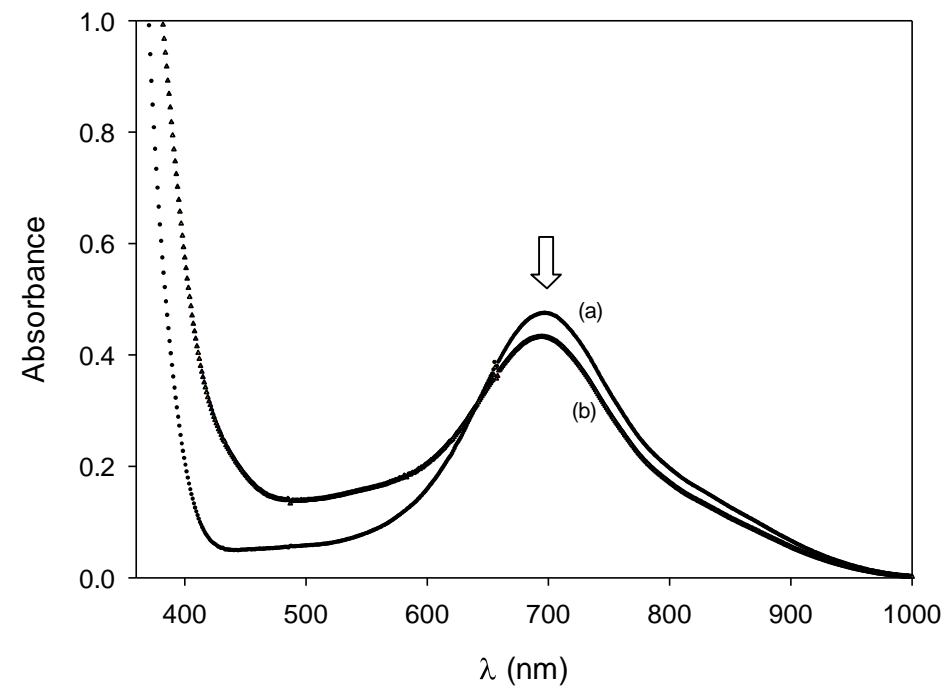

Figure S3. Absorption spectra of the $\left[(\mathrm{N} 4 \mathrm{Py}) \mathrm{Fe}^{\mathrm{IV}}=\mathrm{O}\right]^{2+}\left(1.5 \mathrm{mM}\right.$ in $\left.\mathrm{CH}_{3} \mathrm{CN}\right)$ (a) in the absence and (b) after addition of $20 \mathrm{~mol} \%$ of NHPI.

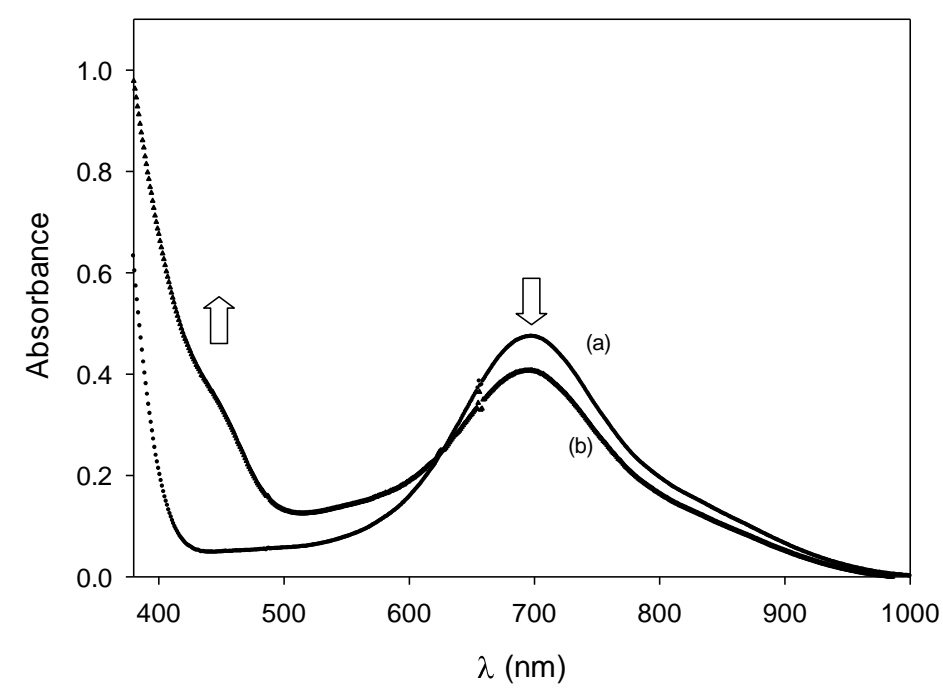

Figure S4. Absorption spectra of the $\left[(\mathrm{N} 4 \mathrm{Py}) \mathrm{Fe}^{\mathrm{IV}}=\mathrm{O}\right]^{2+}\left(1.5 \mathrm{mM}\right.$ in $\left.\mathrm{CH}_{3} \mathrm{CN}\right)$ (a) in the absence and (b) after addition of $20 \mathrm{~mol} \%$ of $4-\mathrm{CH}_{3}$-NHPI. 
Kinetic study of the reaction of $\left[(\mathrm{N} 4 \mathrm{Py}) \mathrm{Fe}^{\mathrm{IV}}=\mathrm{O}\right]^{2+}$ with 4-NO $\mathrm{N}_{2}-\mathrm{NHPI}$

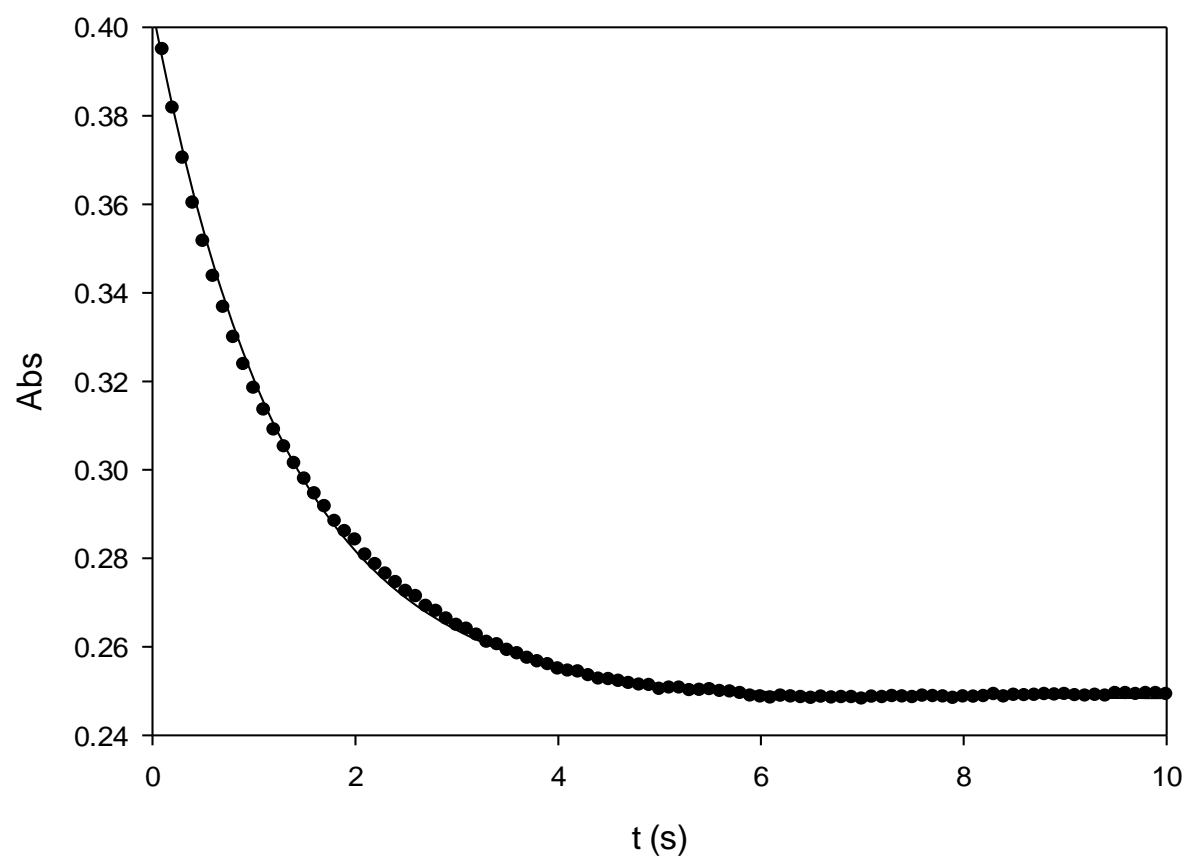

Figure S5. Pseudo-first order decay of the $\left[(\mathrm{N} 4 \mathrm{Py}) \mathrm{Fe}^{\mathrm{IV}}=\mathrm{O}\right]^{2+}\left(1 \mathrm{mM}\right.$ in $\left.\mathrm{CH}_{3} \mathrm{CN}\right)$ in $\mathrm{CH}_{3} \mathrm{CN}$ at $690 \mathrm{~nm}$ in presence of $10 \mathrm{mM}$ of $4-\mathrm{NO}_{2}$-NHPI. 
Kinetic studies of the oxidation of triphenylmethane by $\left[(\mathrm{N} 4 \mathrm{Py}) \mathrm{Fe}^{\mathrm{IV}}=\mathrm{O}\right]^{2+}$ in presence of $\mathrm{N}$ hydroxyphthalimide mediator

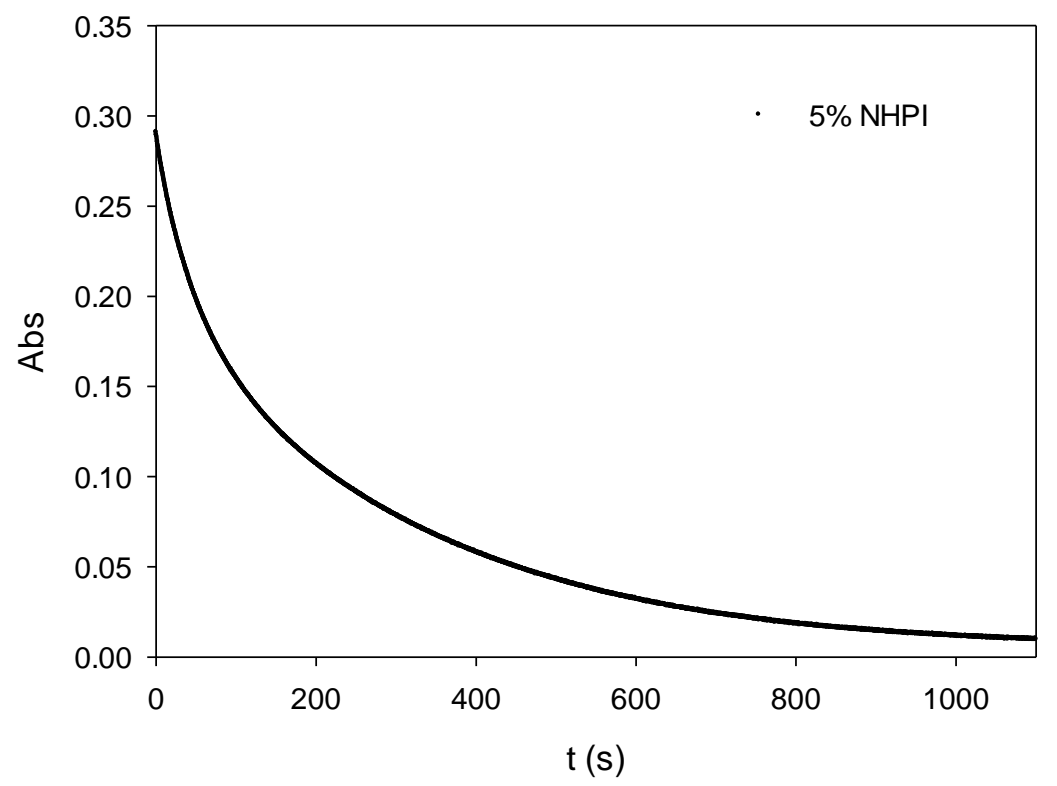

Figure S6. Decay of absorbance recorded at $690 \mathrm{~nm}$ in the oxidation of triphenylmethane $(30 \mathrm{mM})$ with $\left[(\mathrm{N} 4 \mathrm{Py}) \mathrm{Fe}^{\mathrm{IV}}=\mathrm{O}\right]^{2+}(1.5 \mathrm{mM})$ in presence of $5 \mathrm{~mol} \%$ of NHPI in $\mathrm{CH}_{3} \mathrm{CN}$.

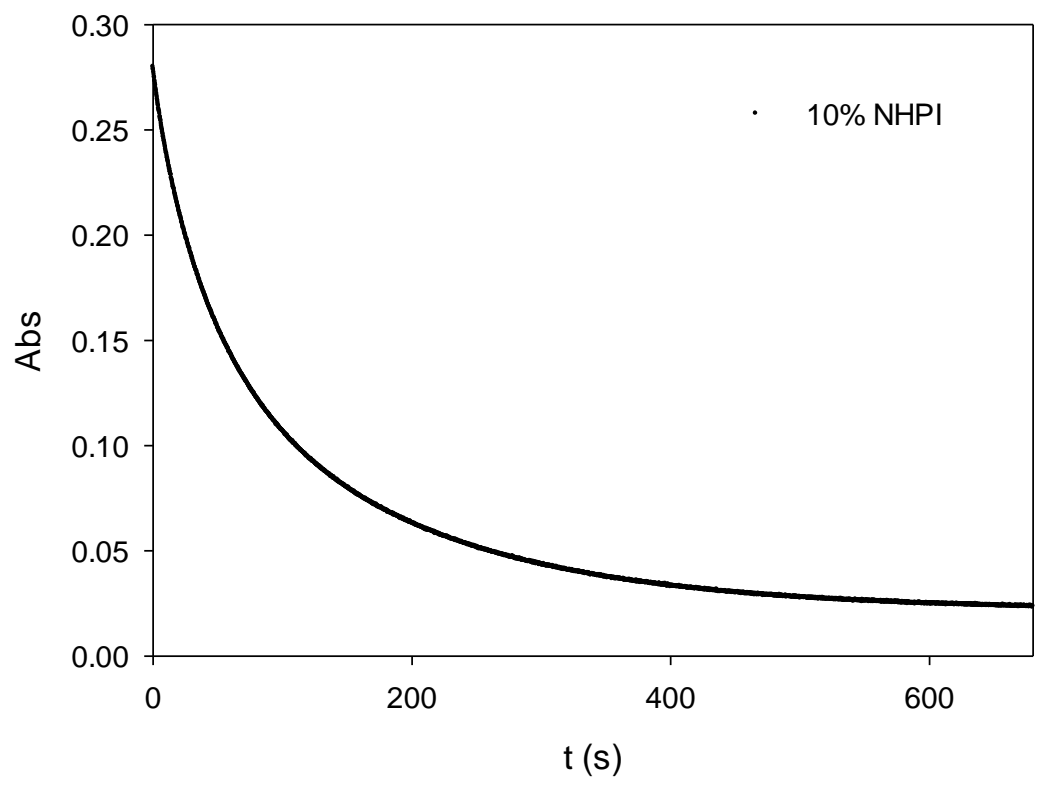

Figure S7. Decay of absorbance recorded at $690 \mathrm{~nm}$ in the oxidation of triphenylmethane (30 $\mathrm{mM})$ with $\left[(\mathrm{N} 4 \mathrm{Py}) \mathrm{Fe}^{\mathrm{IV}}=\mathrm{O}\right]^{2+}(1.5 \mathrm{mM})$ in presence of $10 \mathrm{~mol} \%$ of $\mathrm{NHPI}$ in $\mathrm{CH}_{3} \mathrm{CN}$. 


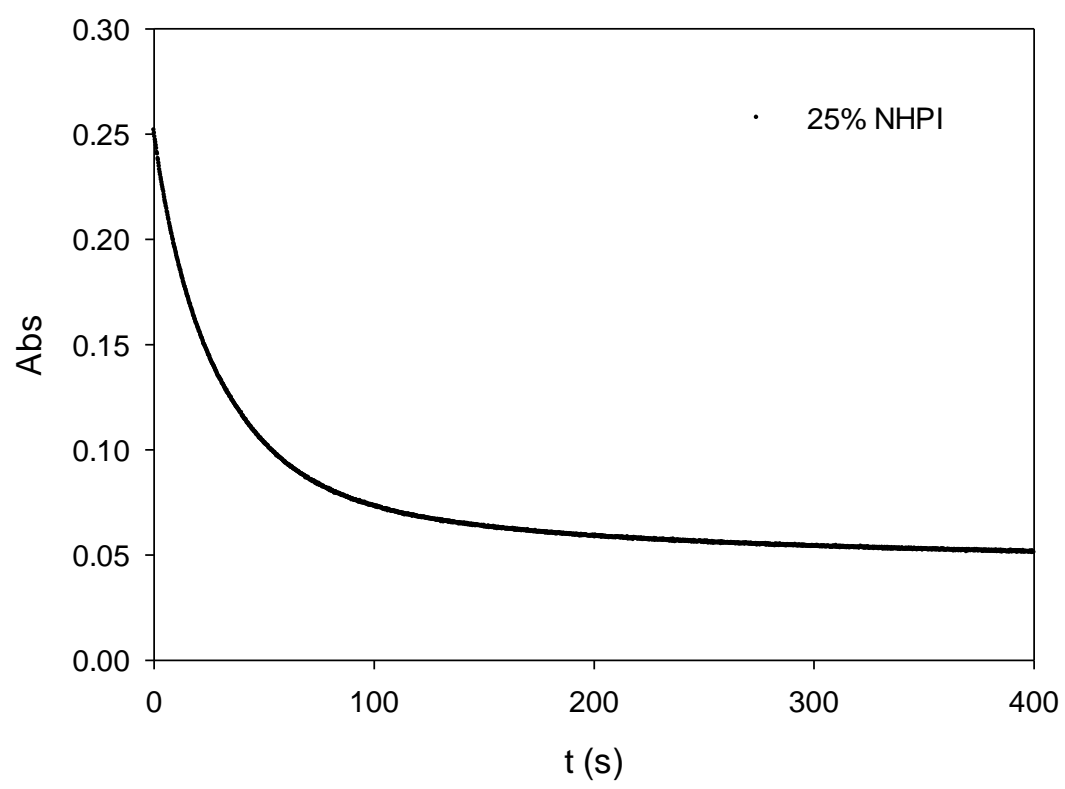

Figure S8. Decay of absorbance recorded at $690 \mathrm{~nm}$ in the oxidation of triphenylmethane (30 $\mathrm{mM})$ with $\left[(\mathrm{N} 4 \mathrm{Py}) \mathrm{Fe}^{\mathrm{IV}}=\mathrm{O}\right]^{2+}(1.5 \mathrm{mM})$ in presence of $25 \mathrm{~mol} \%$ of $\mathrm{NHPI}$ in $\mathrm{CH}_{3} \mathrm{CN}$. 
Kinetic studies of the oxidation of triphenylmethane by $\left[(\mathrm{N} 4 \mathrm{Py}) \mathrm{Fe}^{\mathrm{IV}}=\mathrm{O}\right]^{2+}$ in presence of 20 mol\% of X-N-hydroxyphthalimide mediators

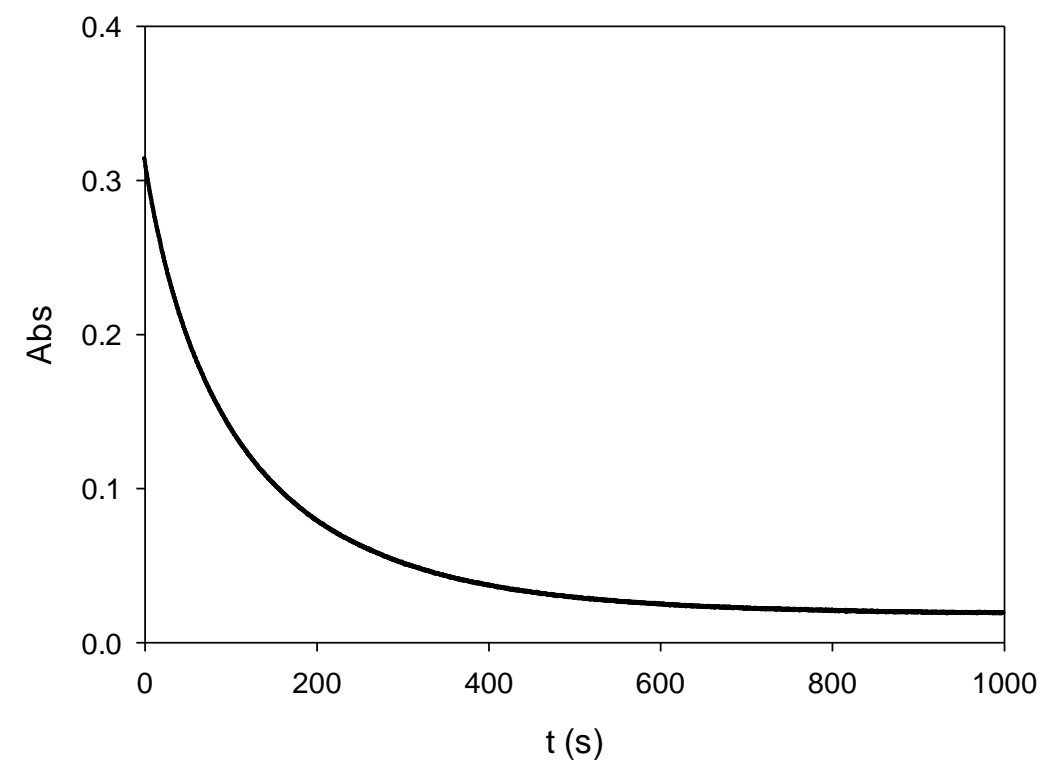

Figure S9. Decay of absorbance recorded at $690 \mathrm{~nm}$ in the oxidation of triphenylmethane (30 $\mathrm{mM})$ with $\left[(\mathrm{N} 4 \mathrm{Py}) \mathrm{Fe}^{\mathrm{IV}}=\mathrm{O}\right]^{2+}(1.5 \mathrm{mM})$ in presence of $20 \mathrm{~mol} \%$ of $4-\mathrm{NO}_{2}-\mathrm{NHPI}$ in $\mathrm{CH}_{3} \mathrm{CN}$.

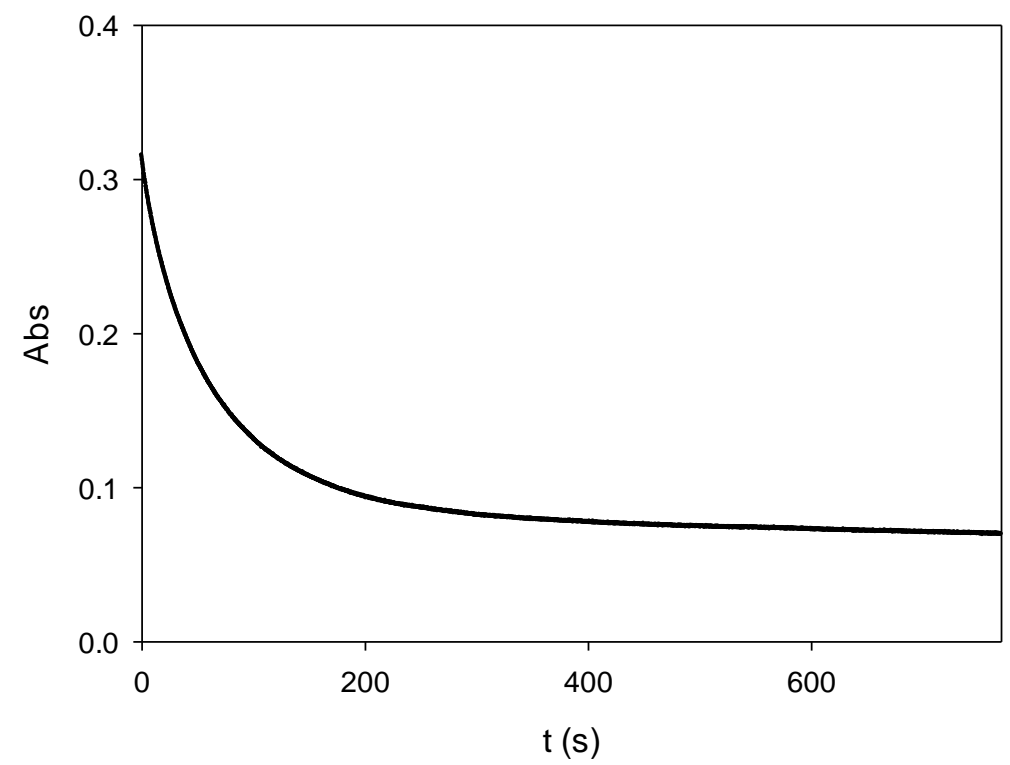

Figure S10. Decay of absorbance recorded at $690 \mathrm{~nm}$ in the oxidation of triphenylmethane (30 $\mathrm{mM})$ with $\left[(\mathrm{N} 4 \mathrm{Py}) \mathrm{Fe}^{\mathrm{IV}}=\mathrm{O}\right]^{2+}(1.5 \mathrm{mM})$ in presence of $20 \mathrm{~mol} \%$ of $4-\mathrm{CO}_{2} \mathrm{CH}_{3}-\mathrm{NHPI}$ in $\mathrm{CH}_{3} \mathrm{CN}$. 


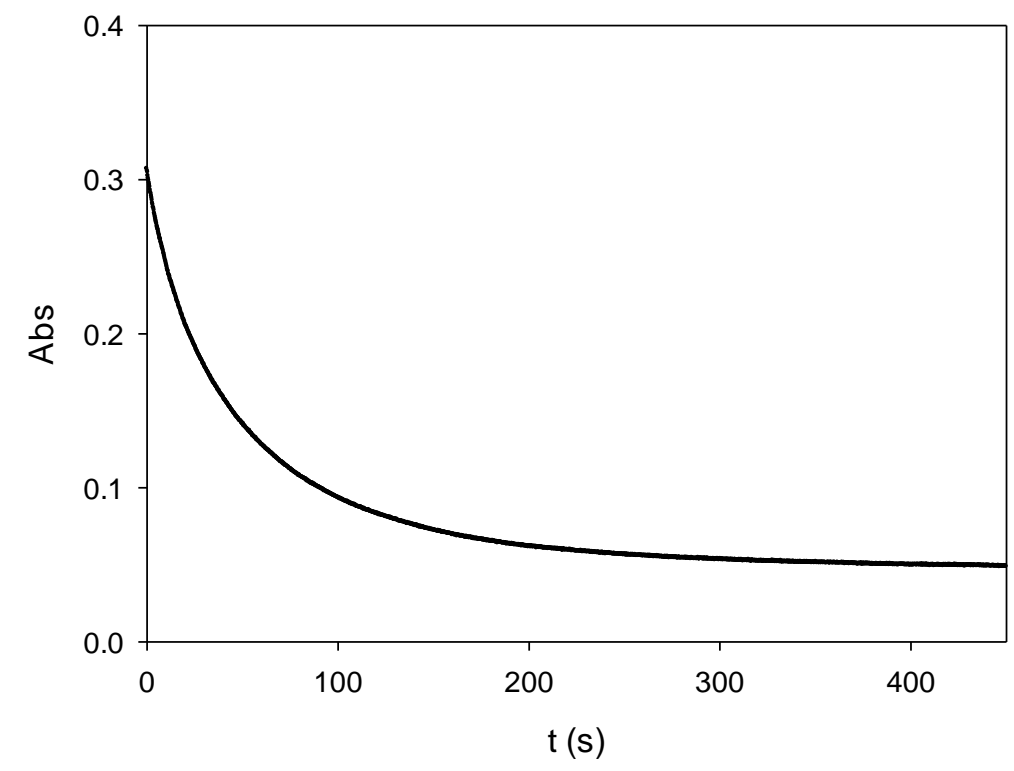

Figure S11. Decay of absorbance recorded at $690 \mathrm{~nm}$ in the oxidation of triphenylmethane (30 $\mathrm{mM})$ with $\left[(\mathrm{N} 4 \mathrm{Py}) \mathrm{Fe}^{\mathrm{IV}}=\mathrm{O}\right]^{2+}(1.5 \mathrm{mM})$ in presence of $20 \mathrm{~mol} \%$ of $3-\mathrm{F}-\mathrm{NHPI}$ in $\mathrm{CH}_{3} \mathrm{CN}$.

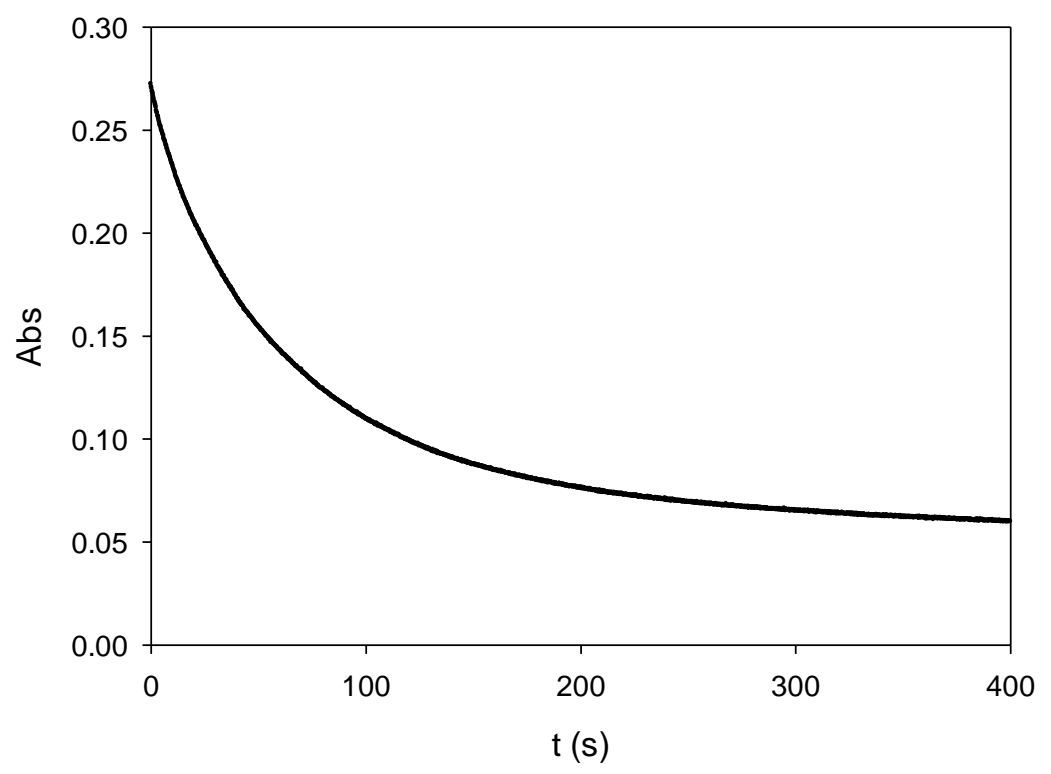

Figure S12. Decay of absorbance recorded at $690 \mathrm{~nm}$ in the oxidation of triphenylmethane (30 $\mathrm{mM})$ with $\left[(\mathrm{N} 4 \mathrm{Py}) \mathrm{Fe}^{\mathrm{IV}}=\mathrm{O}\right]^{2+}(1.5 \mathrm{mM})$ in presence of $20 \mathrm{~mol} \%$ of $4-\mathrm{CH}_{3}-\mathrm{NHPI}$ in $\mathrm{CH}_{3} \mathrm{CN}$. 


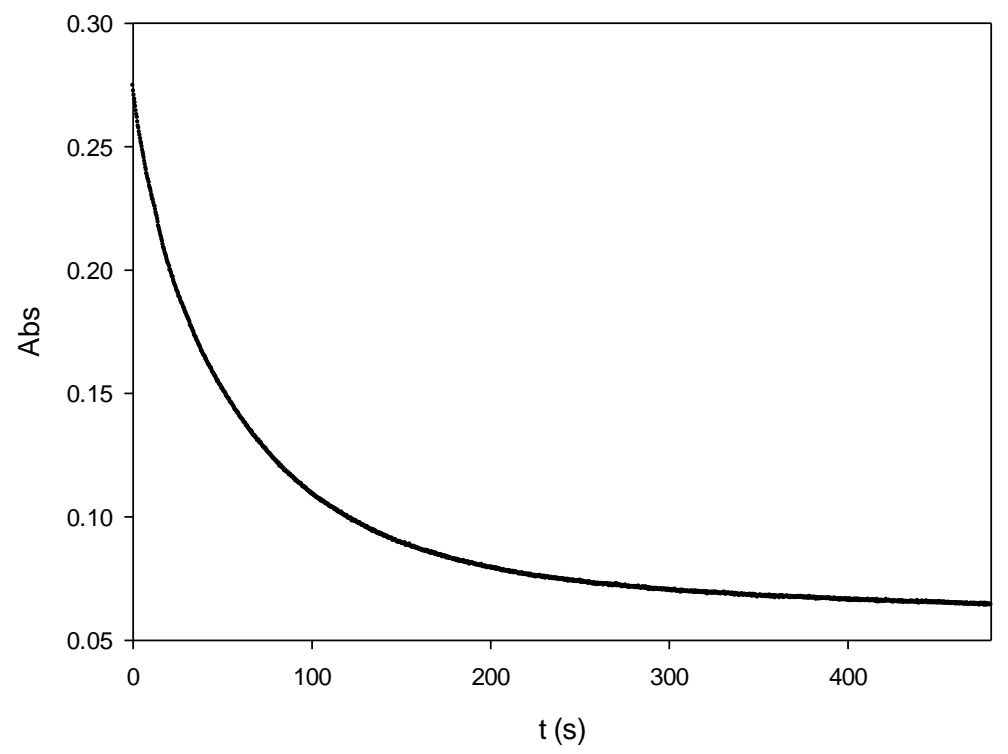

Figure S13. Decay of absorbance recorded at $690 \mathrm{~nm}$ in the oxidation of triphenylmethane (30 $\mathrm{mM})$ with $\left[(\mathrm{N} 4 \mathrm{Py}) \mathrm{Fe}^{\mathrm{IV}}=\mathrm{O}\right]^{2+}(1.5 \mathrm{mM})$ in presence of $20 \mathrm{~mol} \%$ of $4-\mathrm{CH}_{3} \mathrm{O}-\mathrm{NHPI}$ in $\mathrm{CH}_{3} \mathrm{CN}$.

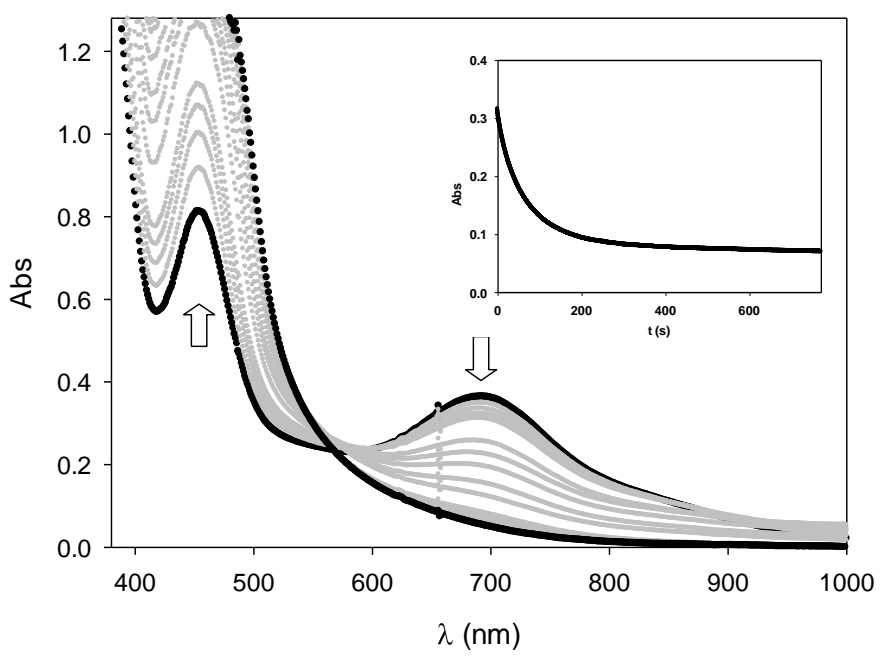

Figure S14. Time-resolved absorption spectra recorded in the oxidation of triphenylmethane (30 $\mathrm{mM})$ with $\left[(\mathrm{N} 4 \mathrm{Py}) \mathrm{Fe}^{\mathrm{IV}}=\mathrm{O}\right]^{2+}(1.5 \mathrm{mM})$ in presence of $20 \mathrm{~mol} \%$ of $4-\mathrm{CO}_{2} \mathrm{CH}_{3}-\mathrm{NHPI}$ in $\mathrm{CH}_{3} \mathrm{CN}$. Inset: decay of absorbance recorded at $690 \mathrm{~nm}$. 


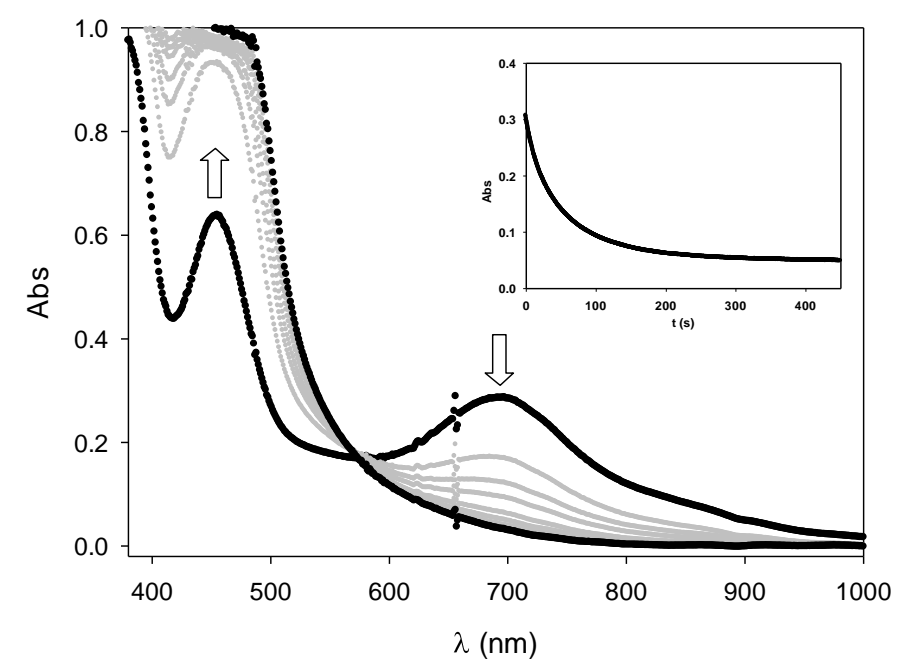

Figure S15. Time-resolved absorption spectra recorded in the oxidation of triphenylmethane (30 $\mathrm{mM})$ with $\left[(\mathrm{N} 4 \mathrm{Py}) \mathrm{Fe}^{\mathrm{IV}}=\mathrm{O}\right]^{2+}(1.5 \mathrm{mM})$ in presence of $20 \mathrm{~mol} \%$ of $3-\mathrm{F}-\mathrm{NHPI}$ in $\mathrm{CH}_{3} \mathrm{CN}$. Inset: decay of absorbance recorded at $690 \mathrm{~nm}$.

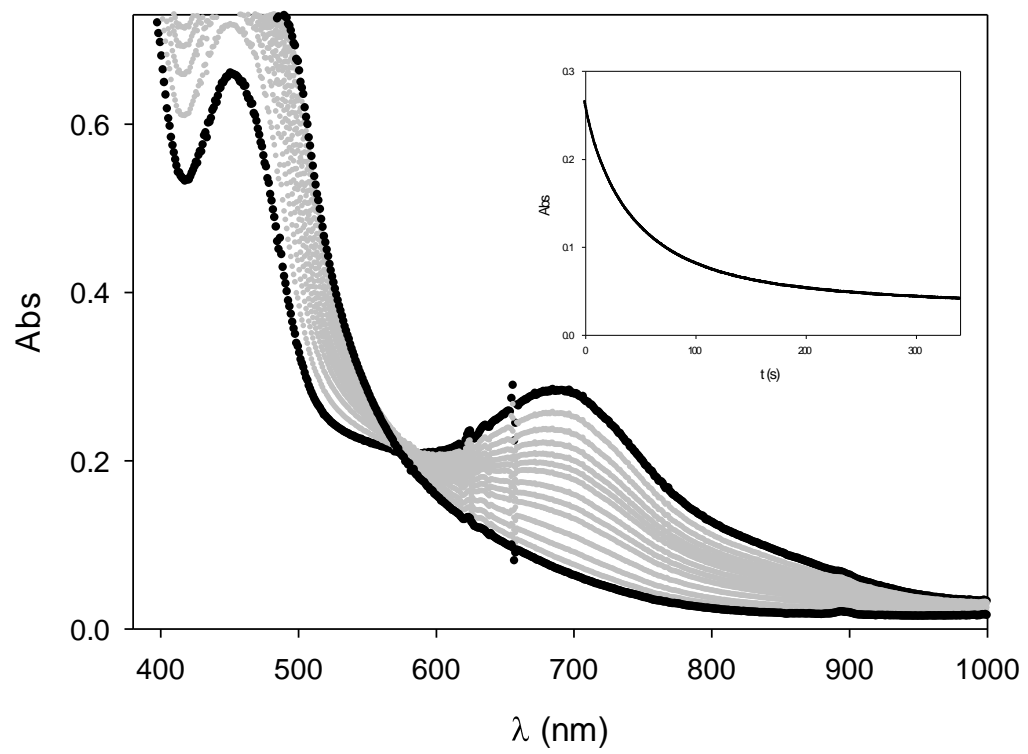

Figure S16. Time-resolved absorption spectra recorded in the oxidation of triphenylmethane (30 $\mathrm{mM})$ with $\left[(\mathrm{N} 4 \mathrm{Py}) \mathrm{Fe}^{\mathrm{IV}}=\mathrm{O}\right]^{2+}(1.5 \mathrm{mM})$ in presence of $20 \mathrm{~mol} \%$ of NHPI in $\mathrm{CH}_{3} \mathrm{CN}$. Inset: decay of absorbance recorded at $690 \mathrm{~nm}$. 


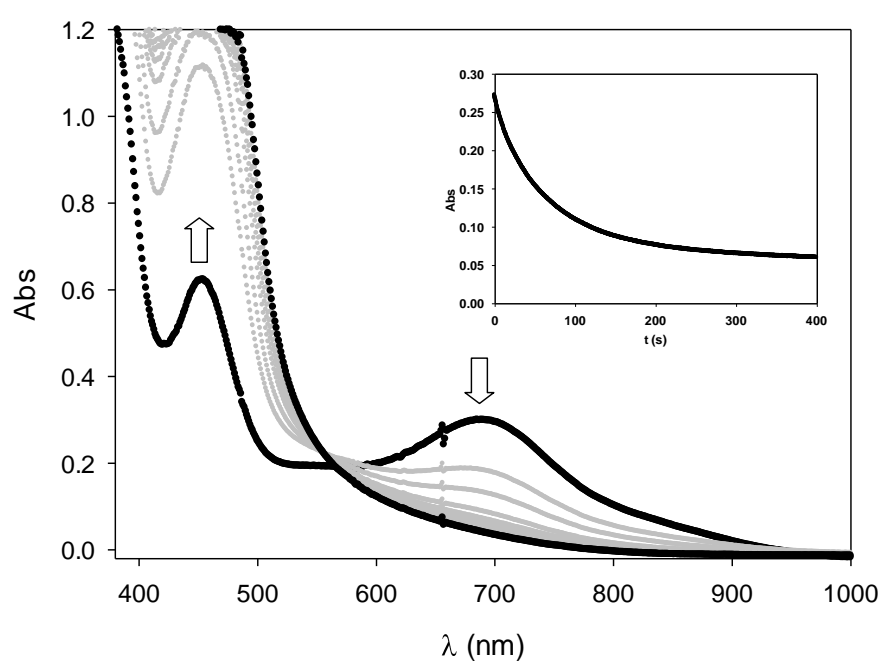

Figure S17. Time-resolved absorption spectra recorded in the oxidation of triphenylmethane (30 $\mathrm{mM})$ with $\left[(\mathrm{N} 4 \mathrm{Py}) \mathrm{Fe}^{\mathrm{IV}}=\mathrm{O}\right]^{2+}(1.5 \mathrm{mM})$ in presence of $20 \mathrm{~mol} \%$ of $4-\mathrm{CH}_{3}-\mathrm{NHPI}$ in $\mathrm{CH}_{3} \mathrm{CN}$. Inset: decay of absorbance recorded at $690 \mathrm{~nm}$.

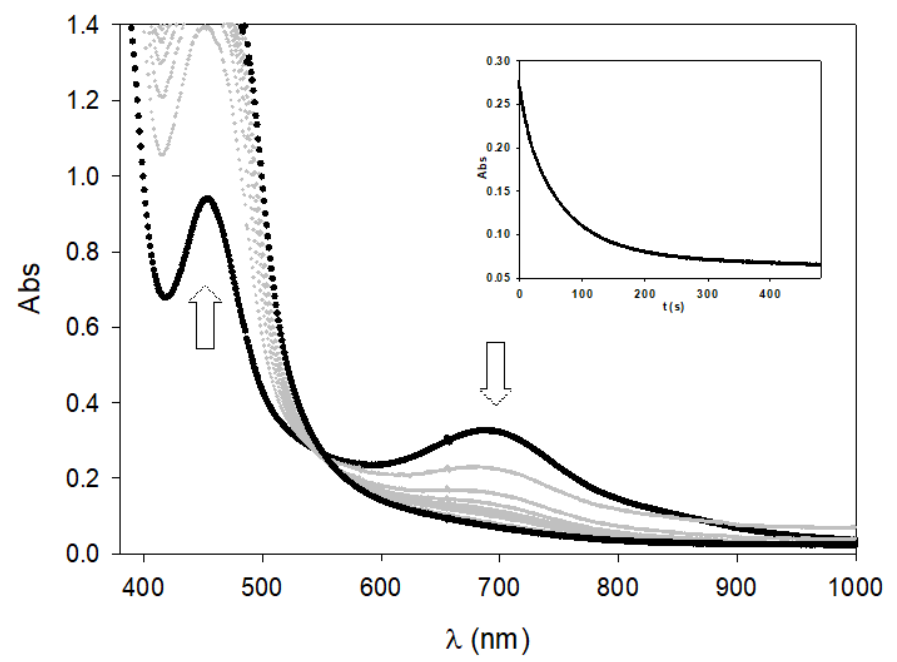

Figure S18. Time-resolved absorption spectra recorded in the oxidation of triphenylmethane (30 $\mathrm{mM})$ with $\left[(\mathrm{N} 4 \mathrm{Py}) \mathrm{Fe}^{\mathrm{IV}}=\mathrm{O}\right]^{2+}(1.5 \mathrm{mM})$ in presence of $20 \mathrm{~mol} \%$ of $4-\mathrm{CH}_{3} \mathrm{O}-\mathrm{NHPI}$ in $\mathrm{CH}_{3} \mathrm{CN}$. Inset: decay of absorbance recorded at $690 \mathrm{~nm}$. 
Kinetic studies of the oxidation of Alkylaromatic Compounds and Cyclohexane by $\left[(\mathrm{N} 4 \mathrm{Py}) \mathrm{Fe}^{\mathrm{IV}}=\mathrm{O}\right]^{2+}$ in presence of $20 \mathrm{~mol} \%$ of $\mathrm{NHPI}$ mediator
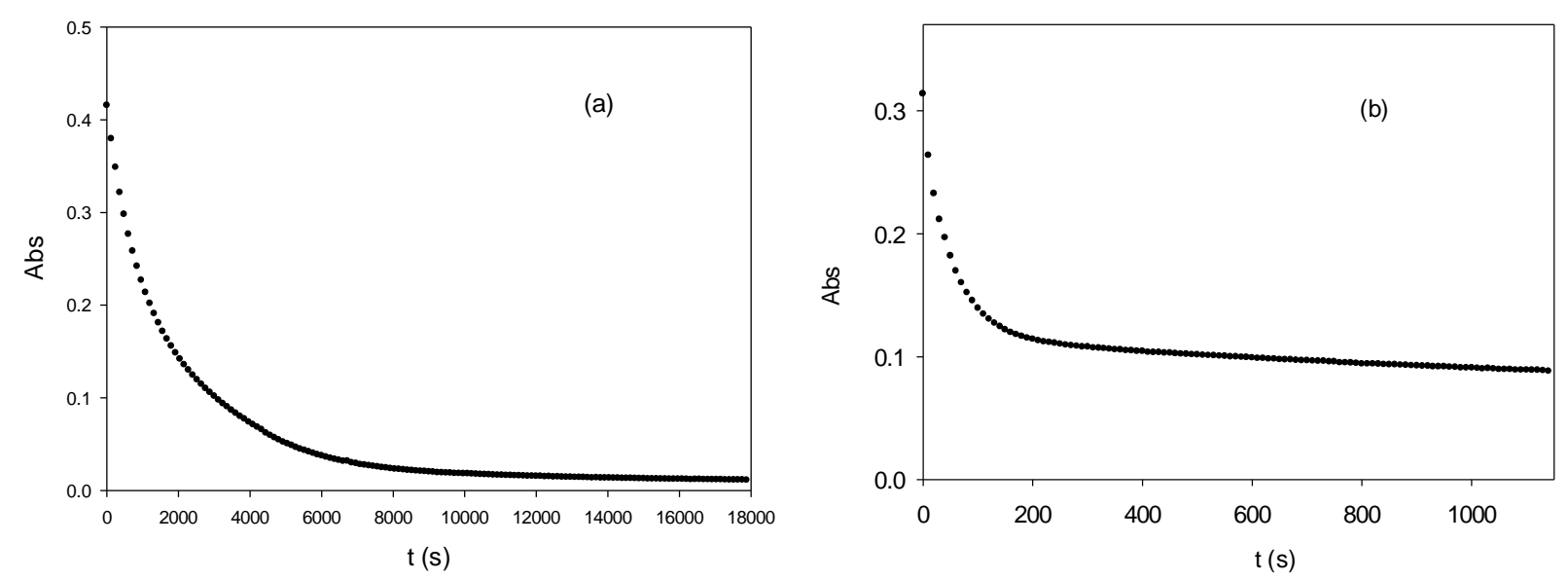

Figure S19. Decay of absorbance recorded at $690 \mathrm{~nm}$ in the oxidation of ethylbenzene $(0.3 \mathrm{M})$ with $\left[(\mathrm{N} 4 \mathrm{Py}) \mathrm{Fe}^{\mathrm{IV}}=\mathrm{O}\right]^{2+}(1.5 \mathrm{mM})$ (a) in the absence and (b) in the presence of $20 \mathrm{~mol} \%$ of NHPI in $\mathrm{CH}_{3} \mathrm{CN}$.
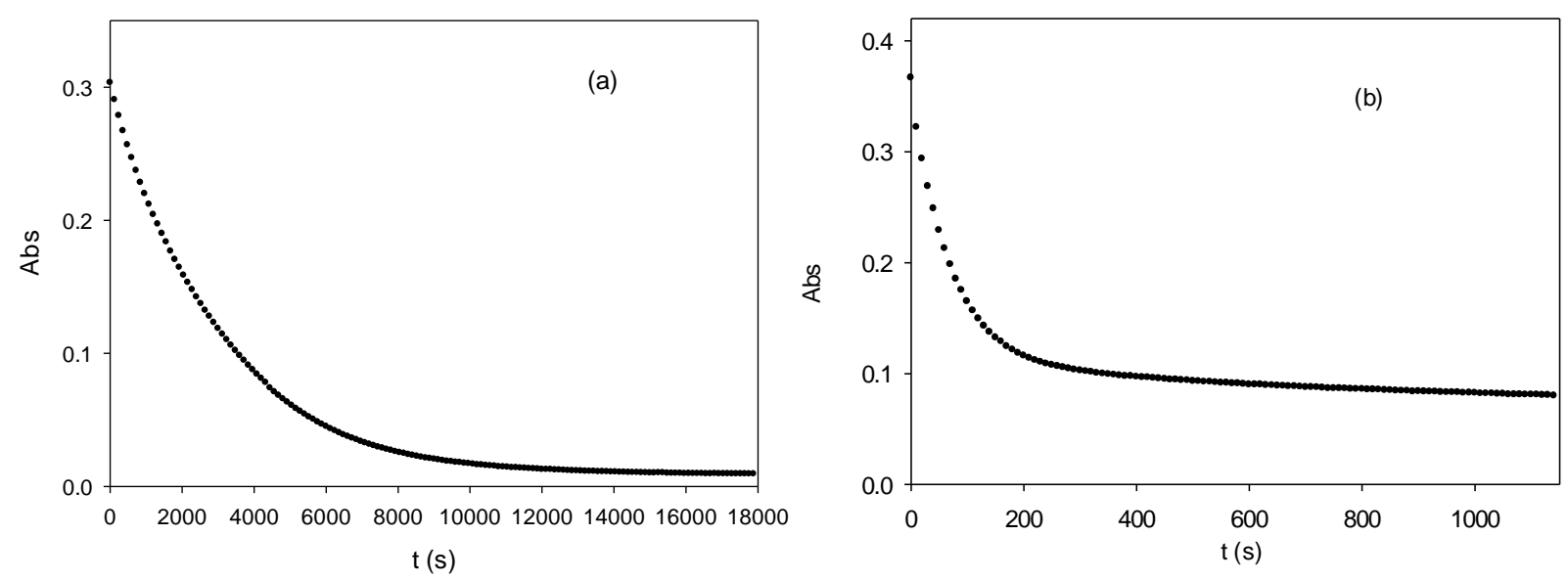

Figure S20. Decay of absorbance recorded at $690 \mathrm{~nm}$ in the oxidation of toluene $(1 \mathrm{M})$ with $\left[(\mathrm{N} 4 \mathrm{Py}) \mathrm{Fe}^{\mathrm{IV}}=\mathrm{O}\right]^{2+}(1.5 \mathrm{mM})$ (a) in the absence and (b) in the presence of $20 \mathrm{~mol} \%$ of NHPI in $\mathrm{CH}_{3} \mathrm{CN}$. 

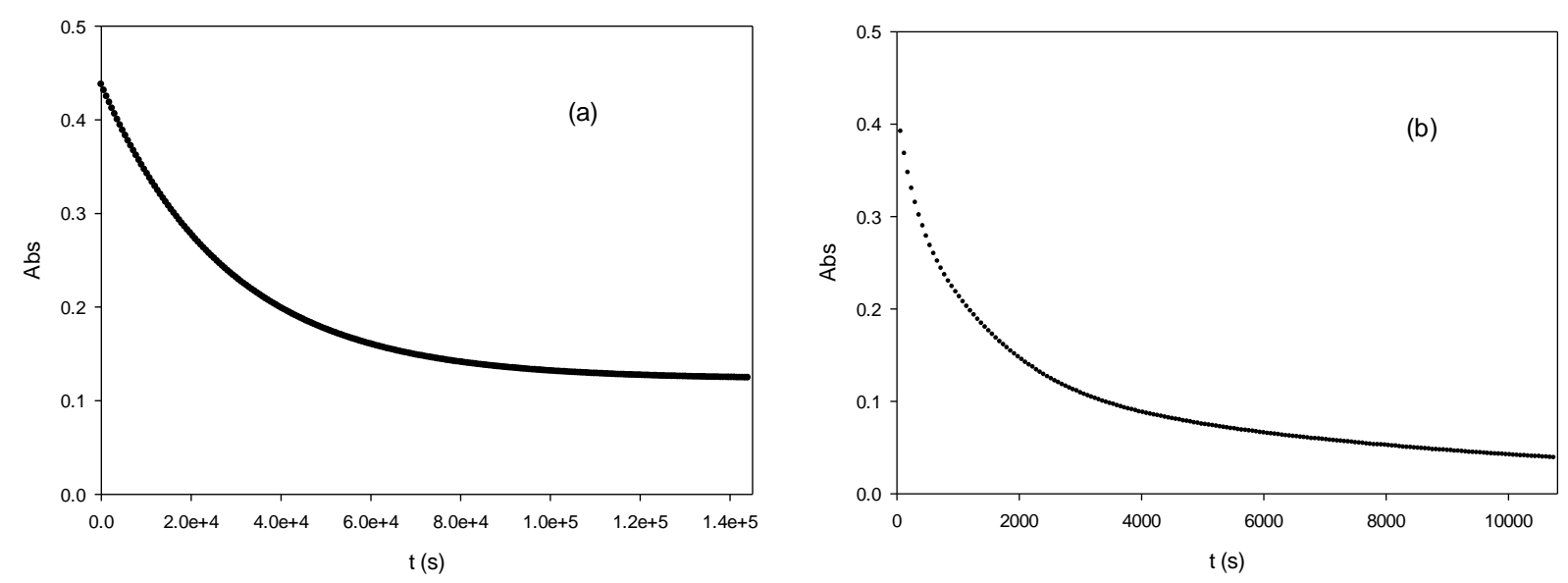

Figure S21. Decay of absorbance recorded at $690 \mathrm{~nm}$ in the oxidation of cyclohexane $(0.8 \mathrm{M})$ with $\left[(\mathrm{N} 4 \mathrm{Py}) \mathrm{Fe}^{\mathrm{IV}}=\mathrm{O}\right]^{2+}(1.5 \mathrm{mM})$ (a) in the absence and (b) in the presence of $20 \mathrm{~mol} \%$ of NHPI in $\mathrm{CH}_{3} \mathrm{CN}$.

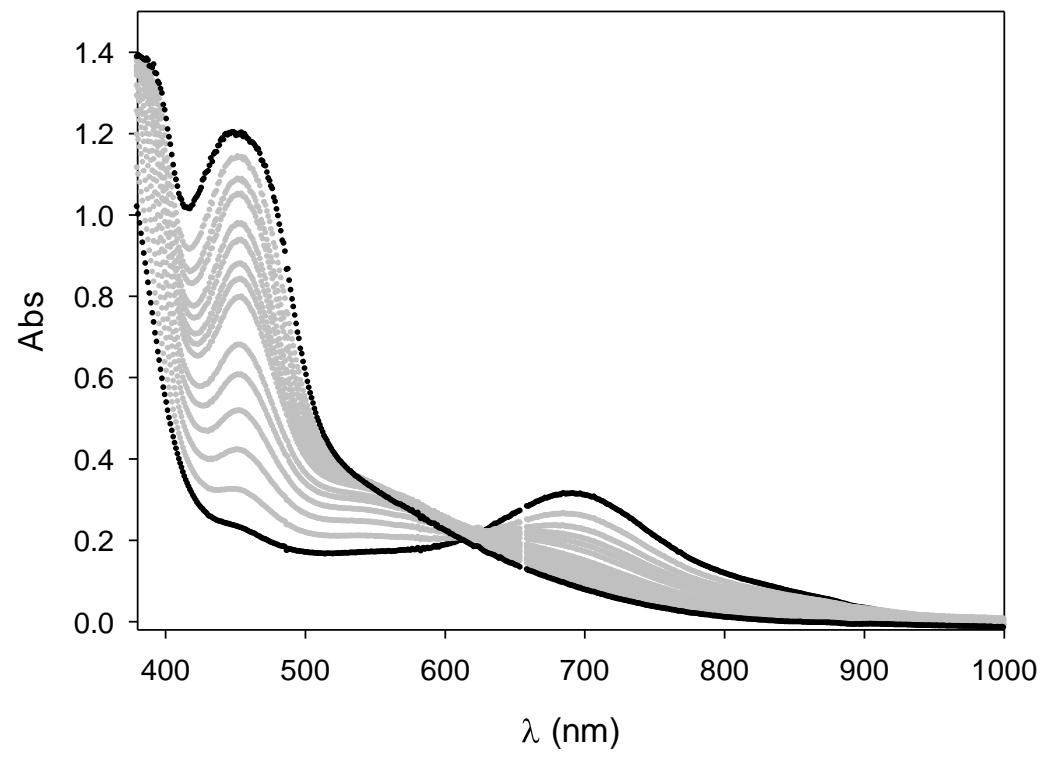

Figure S22. Time-resolved absorption spectra recorded in the oxidation of ethylbenzene $(0.3 \mathrm{M})$ with $\left[(\mathrm{N} 4 \mathrm{Py}) \mathrm{Fe}^{\mathrm{IV}}=\mathrm{O}\right]^{2+}(1.5 \mathrm{mM})$ in presence of $20 \mathrm{~mol} \%$ of $\mathrm{NHPI}$ in $\mathrm{CH}_{3} \mathrm{CN}$. 


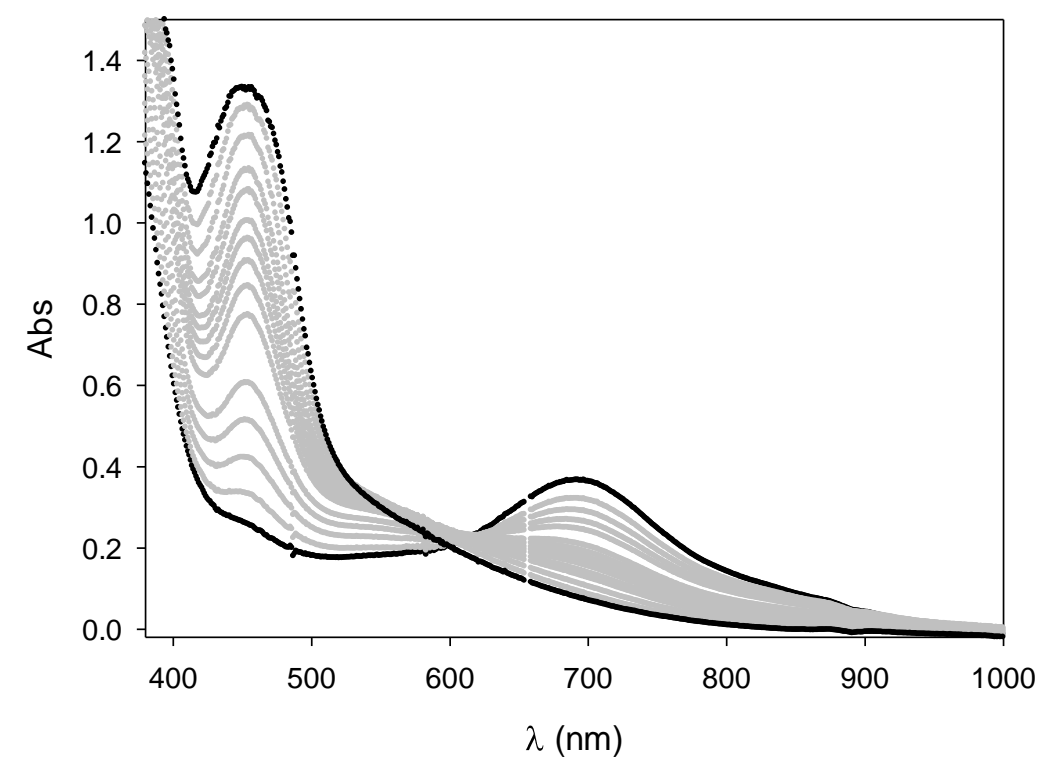

Figure S23. Time-resolved absorption spectra recorded in the oxidation of toluene $(1 \mathrm{M})$ with $\left[(\mathrm{N} 4 \mathrm{Py}) \mathrm{Fe}^{\mathrm{IV}}=\mathrm{O}\right]^{2+}(1.5 \mathrm{mM})$ in presence of $20 \mathrm{~mol} \%$ of NHPI in $\mathrm{CH}_{3} \mathrm{CN}$.

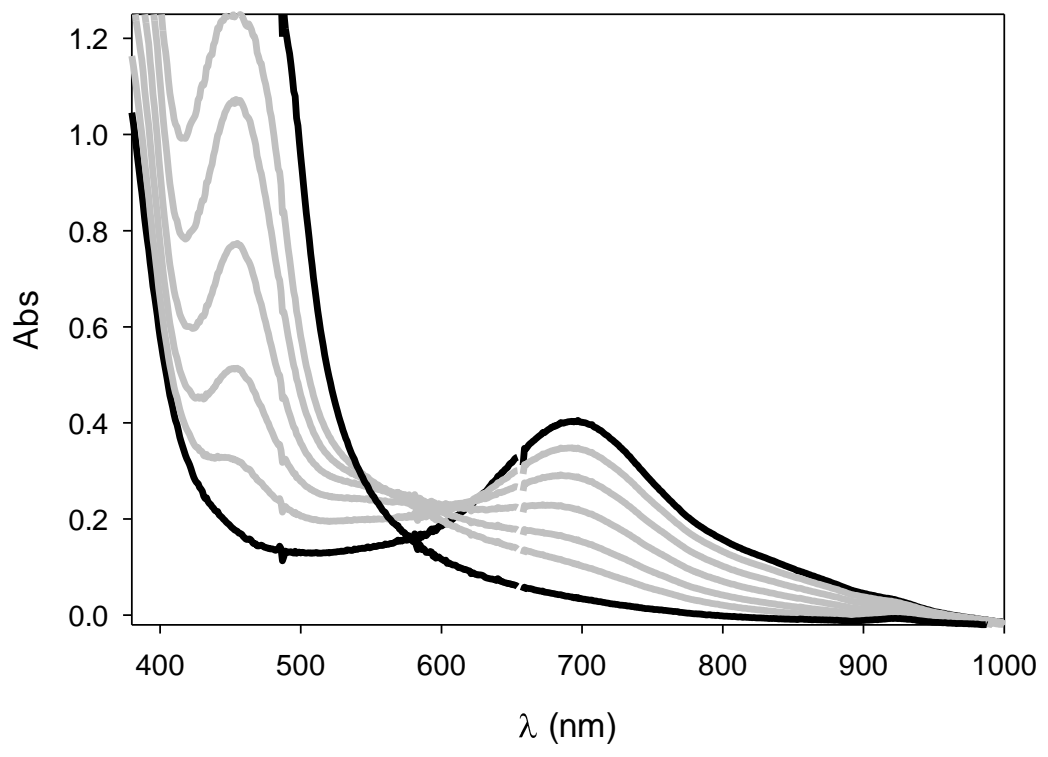

Figure S24. Time-resolved absorption spectra recorded in the oxidation of cyclohexane $(0.8 \mathrm{M})$ with $\left[(\mathrm{N} 4 \mathrm{Py}) \mathrm{Fe}^{\mathrm{IV}}=\mathrm{O}\right]^{2+}(1.5 \mathrm{mM})$ in presence of $20 \mathrm{~mol} \%$ of $\mathrm{NHPI}$ in $\mathrm{CH}_{3} \mathrm{CN}$. 